\title{
Det prehospitale paradoks
}

\author{
«Jeg vil etter beste evne og beste skjønn gi forskrifter om livsførsel til gagn for de syke \\ og jeg vil verge dem mot slikt som fører til skade og urett.»
}

Dette tekstavsnittet fra den hippokratiske ed (1) speiler godt formålsbestemmelsen til den nye helseforskningsloven, som er å fremme god og etisk forsvarlig forskning (2). Forskningen skal være basert på respekt for forskningsdeltakernes menneskerettigheter og menneskeverd. Hensynet til deltakernes velferd og integritet skal gå foran vitenskapens og samfunnets interesser. Disse prinsippene bør stå fjellstøtt.

Den akuttmedisinske hverdag preges av tidskritiske tilstander og pasienter med nedsatt samtykkekompetanse. Evnen til å ha en reell situasjonsforståelse reduseres av nedsatt vitalfunksjon, farmakologisk påvirkning og emosjonelt stress. Samtykke fra pårørende eller andre, såkalt surrogatsamtykke, er vanskelig å innhente når vergen enten er fysisk fraværende eller sterkt emosjonelt påvirket av den kritiske hendelsen. Den akuttmedisinske pasientlogistikken innebærer dessuten et uoversiktlig pasientforløp, med påfølgende krevende innsamling av informasjon fra ulike datakilder. Kritisk syke fraktes ofte gjennom flere avdelinger til flere sykehus innen den tverrfaglige akuttmedisinske helsetjenesten. Forskning og kvalitetsforbedring under slike omstendigheter er vanskelig å utføre, men er likevel svært viktig.

Den nye helseforskningsloven er en etterlengtet opprydning $i$ et tidligere rotete lovverk. Den vil forhåpentligvis oppklare en rekke av uklarhetene som oppstår når kritisk syke blir gjenstand for akuttmedisinsk forskning. Helseforskningsloven $\S 19$ åpner for forskning i kliniske nødssituasjoner der pasienten ikke er i stand til å avgi informert samtykke og det er umulig å innhente samtykke fra nærmeste pårørende. Lovteksten kan gi bedre og mer forutsigbare rammevilkår for akuttmedisinsk forskning. Foreløpig mangler det rettspraksis basert på de nye lovbestemmelsene, og de regionale komiteer for medisinsk og helse- faglig forskning har en krevende og ansvarsfull oppgave med å praktiserer dem. Vi ser frem til å lese deres vurderinger i enkeltsaker.

Det akuttmedisinske tidsskriftet Resuscitation publiserte nylig en amerikansk tverrsnittsundersøkelse av legfolks holdinger til utelatt informert samtykke i akuttmedisinsk forskning (3). Studien avdekket en generell støtte til forskning uten informert samtykke i kliniske nødssituasjoner. Samtidig viste den at holdningene ble påvirket av hvor godt studien ble forklart, av grad av forventet pasientnytte og av hvorvidt de pårørende kunne gi samtykke på pasientens vegne. Resuscitation Outcomes Consortium (ROC), som er et forskningsnettverk av flere amerikanske og kanadiske sentre, har opparbeidet en omfattende erfaring innen klinisk forskning på hjertestans og alvorlig skade. I en nyttig oversiktsartikkel beskriver gruppen fremgangsmåter for vellykket implementering av akuttmedisinsk forskning. De konkluderer med at klinisk akuttmedisinsk forskning av høy kvalitet er mulig hvis strategien for implementering er gjennomtenkt og alle aspekter ved forskning på tidskritiske tilstander behandles seriøst (4).

Alle pasienter har krav på optimal behandling, og forskning er det viktigste virkemidlet for å komme frem til hva dette er. Det kan være vanskelig å definere hva «beste tilgjengelige behandling» er når akuttmedisinske tiltak er dårlig dokumentert og prehospitale tiltak iverksettes ut fra symptomer og ikke diagnose. Akuttmedisinsk forskning er underprioritert. Behovet for økt forskningsinnsats er anerkjent også internasjonalt (5).

Når tiden er knapp, pasienten bevisstløs, intervensjonene kritiske og forskning essensielt, er det krevende å oppfylle de absolutte regler om pasientintegritet. Situasjonens kompleksitet er likevel ingen unn- skyldning for ikke å drive systematisk kvalitetsforbedring og eksperimentell forskning. Vi må heller se det som en ekstra utfordring på veien mot bedre akuttmedisinsk omsorg for pasientene. I dag innføres ofte nye rutiner i tjenesten uten at effekten av dem er vitenskapelig dokumentert. Det er et paradoks at det er vanskeligere å forske på ny prehospital behandling enn å innføre den samme behandlingen uten vitenskapelig vurdering av nytte og risiko et prehospitalt paradoks.

\section{Marius Rehn}

\section{marius.rehn@snla.no}

Stiftelsen Norsk Luftambulanse

Postboks 94

1441 Drøbak

og

Oslo universitetssykehus, Ullevål

\section{Andreas Krüger}

Stiftelsen Norsk Luftambulanse

og

St. Olavs hospital

Oppgitte interessekonflikter: Ingen

\section{Litteratur}

1. Ruyter K, Førde R, Solbakk J. Medisinsk etikk en problembasert tilnærming. Oslo: Gydendal Akademisk, 2000

2. LOV-2008-06-20 nr 44. Lov om medisinsk og helsefaglig forskning (helseforskningsloven). www.lovdata.no/all/hl-20080620-044.html (15.12.2009).

3. Biros MH, Sargent C, Miller K. Community attitudes towards emergency research and exception from informed consent. Resuscitation 2009; 80: 1382- 7 .

4. Pepe PE, Copass MK, Sopko G. Clinical trials in the out-of-hospital setting: rationale and strategies for successful implementation. Crit Care Med 2009; 37 (1 suppl): $91-101$.

5. Stuckler D, King L, Robinson $\mathrm{H}$ et al. WHO's budgetary allocations and burden of disease: a comparative analysis. Lancet 2008; 372: 1563-9.

Manuskriptet ble mottatt 15.12. 2009 og godkjent 28.1. 2010. Medisinsk redaktør Petter Gjersvik. 